\title{
Knowledge on Japanese People's Beliefs in the Anime Natsume Yuujinchou
}

\author{
Idah Hamidah, Muammar Kadafi and Dera Zuliyanti \\ ${ }^{1,2,3}$ Universitas Jenderal Soedirman \\ idahamidah75@yahoo.com
}

Article History: Submitted date 2018-11-13; Accepted date 2018-11-30; Published date 2018-11-30

\begin{abstract}
Japanese people's trust is a belief inherited from time immemorial and is still maintained today. This can be seen from popular works that still raise traditional Japanese values. One of them is the anime Natsume Yuujinchou raising the values of Japanese people's beliefs about gods or Us and the life of the unseen. This study was about to describe the beliefs of Japanese people found in the anime Natsume Yuujinchou. The research method used to explore Japanese people's trust is a qualitative descriptive method. The approach used is literary anthropology. Found five concepts of Japanese people's beliefs from the anime, namely, 1) trust in the existence of a god; 2) trust in inanimate objects and can live if entered by the spirit; 3) belief in vengeance or punishment invisibly; 4) belief in the manifestations of kindness and evil from the spirit; 5) belief in souls (spirits) or spirits (spirits) in plants or animals The conclusions of this study are Japanese people's beliefs contained in the Natsume Yuujinchou anime in the form of supernatural concepts, soul concepts (souls) and spirits (spirits), and the concept of retaliation (tatari).
\end{abstract}

Keywords: anime, god, japanese, reliance, spirit 


\begin{abstract}
Abstrak
Kepercayaan rakyat Jepang adalah kepercayaan yang diwariskan dari zaman dahulu kala dan masih dipertahankan hingga saat ini. Hal ini terlihat dari karya populer yang masih mengangkat tentang nilai-nilai tradisional Jepang. Salah satunya adalah anime Natsume Yuujinchou mengangkat nilai-nilai kepercayaan rakyat Jepang tentang dewa atau Kami serta kehidupan alam gaib. Penelitian ini mendeskripsikan kepercayaan rakyat Jepang yang terdapat pada anime Natsume Yuujinchou. Metode penelitian yang digunakan untuk menggali kepercayaan rakyat Jepang adalah metode deskriptif kualitatif. Pendekatan yang digunakan adalah antropologi sastra. Ditemukan lima konsep kepercayaan rakyat Jepang dari anime tersebut yaitu, 1) kepercayaan terhadap adanya keberadaan sesosok dewa; 2) kepercayaan terhadap benda mati dan dapat hidup jika dimasuki oleh roh; 3) kepercayaan terhadap pembalasan atau hukuman secara gaib; 4) kepercayaan terhadap manifestasi kebaikan dan keburukan dari roh; 5) kepercayaan terhadap jiwa (souls) atau roh (spirits) pada tanaman atau binatang Kesimpulan penelitian ini adalah kepercayaan rakyat Jepang yang terdapat dalam anime Natsume Yuujinchou berupa konsep alam gaib, konsep jiwa (souls) dan roh (spirits), dan konsep pembalasan (tatari).
\end{abstract}

Kata kunci: anime, dewa, jepang, kepercayaan, roh

\title{
1. INTRODUCTION
}

Japan is one country that is rich in culture inherited from one generation to another generation from the distant past up to the present. A part of its culture is the beliefs of the Japanese people. These beliefs are derived from Shinto teachings, for which its development process is intertwined with Buddhism (Ross, 2007, p.11). Amidst modern life, the beliefs still exist and remain practiced by Japanese people themselves. Even through their creations, these beliefs are discussed and introduced to all fans of the creations (Addis, 1985, p.11).

One of the anime that presents the theme of Japanese beliefs is Natsume Yuujinchou. This anime is an adaptation of the manga of the same name, Natsume Yuujinchou, written by Yuki Midorikawa. This was published for the first time by the Hakusensha publisher in 2005. Until now, in Japan, the manga is still ongoing and the latest publication is the 20th volume. This Manga is also published in Indonesia by Elex Media Komputindo. Currently, the anime has five seasons: the first season consists of 13 episodes in 2008, the second season consists of 13 episodes in 2009, the third season consists of 13 episodes in 2011, the fourth season consists of 
13 episodes in 2012, and The fifth season is in 2016 . The five seasons are directed by Takahiro Omori.

The anime Natsume Yuujinchou tells about an adolescent junior high school student who is named Natsume Takashi. Natsume has the ability to acknowledge and see the presence of unseen spirits. Natsume also inherited a book called Yuujinchou. The book contains the names of unseen spirits that were successfully defeated by Natsume's grandmother, Natsume Reiko, before she passed away. Since inheriting the book, Natsume always faced unseen spirits and are involved in troubles with them. During the course of his story, Natsume is accompanied and often saved by an invisible creature namely Madara or usually called as Nyanko Sensei when he is involved in troubles with unseen spirits.

The theme of the supernatural is one of approach of the genre of mystery of popular creations, not only in Japan but also in almost all parts of the world. Compared to other themes, the supernatural is always tied to a certain belief context. Such ties to this context make it desirable to uncover Japanese people beliefs contained in the anime Natsume Yuujinchou. In this way, it is possible to understand the values contained in Japanese society and culture.

One previous research that studied anime Natsume Yuujinchou is a research written by Pertiwi (2014)entitled Analysis of Japanese Folklore in the Anime Gegege No Kitarou, Inuyasha, and Natsume Yuujinchou. The research presented a theme of Japanese folklore that studied Japanese people beliefs in the three anime. Japanese people beliefs contained in the three anime are in the form of description of spiritual creatures and the concept of a supernatural world believed by Japanese people. The research used a dynamic structuralism approach that analyzed elements in the literary work in the forms of intrinsic and extrinsic elements, and so a connection between a literary work and reality can be seen. In contrast to the previous research, this research uses a literary anthropological approach that specifically positions a work of creation as an object of anthropological study.

\subsection{Literary anthropology}

Literary anthropology consists of the two words of "literature" and "anthropology". According to Ratna (2011), literary anthropology is an analysis of literary work that contains anthropological elements. In this relation, it is clear that the literary work occupies a dominant 
position; on the contrary, the anthropological elements are as complements. Because the anthropology discipline is very large, its relation to literature is limited to the cultural elements contained in the literary work. It is in accordance with the nature of literature itself, that literature is a result of cultural activities. Another opinion was conveyed by Koentjaraningrat (in Ratna, 2011, p.28) that literary anthropology is an analysis and an understanding of literary work in relation to culture.

The significance of analysis of cultural elements according to Sudikan (Ratna, 2011) in the literary work is absolutely needed as a comparison to literary psychology and literary sociology. Second, literary anthropology is necessary considering the cultural richness that is handed down from ancestors.

Analysis of literary anthropology is an effort to try to give an identity to the literary work by considering it as containing a certain aspect that is a relation of cultural characteristics. This certainly refers to the definition of literary anthropology. The characteristics, among others, are having tendency to the past, primordial image, and archetype image. Other characteristics include containing the aspects of local wisdom with their respective functions and positions, and talking about national ethnic groups with their sub-categories such as lineage, clan, and caste. The relevant forms of tendency also emerge as certain associations, such as a group of people from certain area as well as certain groups.

Related to the cultural elements in literature, Soekanto (in Warsito, 2012, p. 71) limited the cultural elements into seven divisions:

1. System of technology and life equipment of human being, such as houses, clothes, household utensils, and equipment related to human beings in their daily life.

2. System of livelihood, such as agriculture, husbandry, and fishery through their respective economic systems and productions; this system is being developed along with the increase in the creation capacity of human beings and other influences.

3. Social system and organization concerning social matters such as marriage, divorce, inheritance law, kinship system, and so on.

4. Language, which is generally as means of social intercourse, value inheritance, and spreading information. 
5. Art, which in general is divided into two: art that can be enjoyed by viewing such as sculpture, carving, and painting; and art that is audible (enjoyed using auditory sensory) such as music and literature.

6. System of knowledge such as knowledge of surrounding environment, flora, fauna, the human body, and so on.

7. System of religion, as the many kinds of human being experiences in relation to subjectivity and various beliefs. The important elements in religion is the system of beliefs and the system of religious ceremonies.

\subsection{Theory of Religion}

The concern of anthropology about religion is great. Religion itself is all systems of human being actions to attain goals by relying themselves upon powers such as spirits, ancestors, gods, or God Almighty. Meanwhile, these are the basic elements of religion according to Durkheim (in Koentjaraningat, 1998, p. 201):

1. Religious emotion (sensation) that triggers human beings to be motivated to behave religiously.

2. System of beliefs or human being fantasies about the shape of the world, nature, supernatural nature, life, death, and so on.

3. System of rites and religious ceremonies that aim to find a relation to the supernatural world based on the system of beliefs.

4. Religious groups or social unities conceptualizing and activating religion along with the religious ceremonies.

5. Physical equipment used in the rites and religious ceremonies.

Every human being must be conscious of the invisible nature in this world beyond human mind limits. According to Koentjaraningrat (1998, p. 203), such world is called as the supernatural world. These occupy the supernatural world:

1. Gods, who are creatures described by humans as having names, shapes, characteristics, and explicit personalities; in a religion, there must be levels of gods that differentiate high gods and low gods. In addition, the gods of nature are also known, such as the god of sun, the god of moon, the god of sky, the god of earth, the god of mountain, the god 
of wind, the god of river. As well, there are gods that protect human beings' activities and possessions (such as the god of hunting, the god of agriculture, the god of prosperity, the god of war).

2. Spirits, spirits of ancestors of other spirits, ghosts, and others are considered as the occupants of the spiritual world by many ethnic groups in the world. The spirits are considered as occupying the surrounding environment where human beings reside, such as forest, house, cave, tree, stone, and so on; the spirits are believed to be able to penetrate into the human body, into animals, and even into things.

3. Magic power is an object of belief which is very important in many religions in the world and considered as being present through indications (natural indications), things (human figure, human body, animal, plant, voice), and also extraordinary incidents beyond human mind limits.

\subsection{Theory of Religious Evolution}

According to Lowie (Lowie, 1937), Edward Burnett Taylor (1832-1917) was an anthropologist from England who previously obtained education of literature and Greek and Classical Roman culture and was later on interested in anthropology. According to his own explanation, an anthropologist aims to study as many as possible various cultures in the world and find as many similar elements as possible, so that this may show that the history of human cultural evolution is from one level to another level. The main elements of culture include system of religion, beliefs, literature, customs, ceremonies, and art.

In Koentjaraningrat (1998, p. 194), E.B Taylor in his book of two volumes entitled Primitive Culture: Language Art and Custom (1874) presented his theory that human religious behavior occurs because of the following causes:

1. Humans beginning to be aware of the existence of a concept of spirits;

2. Humans recognizing the presence of many indications that could not be explained by the mind;

3. Human desire to face many crises they always face in their life cycle;

4. Extraordinary incidents faced by humans in their surroundings; 
5. The presence of sensation or emotion in the form of a sense of unity that emerges in the human soul as part of society;

6. Humans receiving God's decree.

According to E.B Taylor (in Koentjaraningat, 1998, p. 195), the beginning of human beings becoming aware of their religious behavior is from the human awareness of a concept of spirits that result from the following causes:

1. An obvious difference in human beings that are alive and that are dead. An organism that in a certain time can move means that it is live, but if it can no longer afterwards, it means that it is dead. Therefore, humans begin to be aware of a power that causes the movement, namely the soul.

2. The phenomenon of dream, as in dreams, humans see themselves in other places (not in the place where they sleep), and thus, humans begin to differentiate between the physical body that is on the bed and another part that goes to other places. The part is called the soul.

The abstract characteristics of the soul results in the human belief that souls can live directly, apart from the physical body, and only able to leave the body while sleeping or fainted. Because in such times the power of life flies, the body is in a weak condition. Nevertheless, Taylor argued that although in a flying condition, the relation between physics and spirit while sleeping or being fainted still exists. Only when the human is dead, his soul flies separately and the relation between the physical being and the spirit is broken forever. It is obviously clear if the physical body is destroyed into dust in the ground, or burns up into ashes in the fire of a dead body burning ceremony. The soul, which has been free from its physical being, can act however it wants. The universe is full of free souls, which is not called by Taylor as a soul anymore but as a spirit. Therefore, human beings transform their awareness of the existence of soul into a belief in spirits.

In the oldest level in religious evolution, human beings believed that such spirits are those that occupy the places surround them. The spirits that reside near the human residence, have a visible body which cannot be sensed by human five senses, and are able to do things 
that cannot be done by human, obtain a very important place in human life. Thus, the spirits become objects of respect and worship, accompanied by many ceremonies such as prayer, ritual offerings, or religious offerings. Such religion is called by Taylor as animism.

After that, Taylor continued the theory of the origin of religion with an explanation on religious evolution based on the way of thinking of evolutionism. Taylor stated that animism, which is basically a belief in spirits that reside in the places that surround human residence, is the oldest religion. In the second level in the religious evolution, humans believed that the natural movement is also caused by the existence of spirits behind the natural incidents and phenomena. Rivers that flow and then go to the sea, volcanoes that erupt, earthquakes, tornadoes, the sun movement, the growth of plants, and essentially every natural movement, are caused by spirits that reside in nature.

The natural spirits were then personified and considered as creatures that have a personality along with desire and mind, that are called as gods of the nature. In the third level of the religious evolution, in line with the occurrence of state structure in society, there also occurred a belief that the gods of the nature also live in a state structure, similar to the human world. Therefore, there is also a structure of gods' positions, starting from the king of the gods as the highest god down to the lower gods. Gradually, the similar structure generated an awareness that essentially, all gods are manifestation of the only one god, that is the highest god. As a result, a belief in one supreme god developed and monotheism religions are present as the last level in the religious evolution.

\subsection{Japanese people beliefs}

In Japanese people beliefs, there are certain beliefs or religions that are adhered up to the present. One of the beliefs considered as the oldest belief and as the religion of the indigenous people of Japan is Shintoism. According to Harumi Befu (Danandjaja, 1997) Shintoism is actually a combination of primitive beliefs which cannot easily be considered as a religion, or even as beliefs. Therefore, this religion may be considered as a combination of primitive beliefs and practices that are related to souls, spirits, ghosts, and so on. Thus, Shintoism according to Danandjaja (1997) is folk beliefs because these beliefs are based on beliefs in supernatural powers in nature. 
Also, according to Dahsiar (in Pranata dan Kebudayaan Jepang, 1976, p. 25), the folk beliefs are also called as Minkan shinko which is a form of belief that has doctrine, philosophy, and noble ethics. Minkan shinko or folk beliefs is not categorized as a world religion such as Buddhism, Christianity, Islam, and so on, that have certain elements such as holy books, leaders or founders, and followers who spread these religions everywhere.

The following are the concepts that Japanese people have regarding the supernatural, according to Danandjaja (1997):

1. For Japanese people, all natural phenomena that are animate or inanimate, even manmade items, have the potential to come to live if penetrated by spirits.

2. Magical powers or functions of spirits or gods may have direct or indirect relations to the characteristics of the place where they reside. Another typical characteristic of spirits or gods in Japan is identification by certain places of worship, such as spirits of a tree or protector gods of a certain place.

3. The places where most spirits reside are identified as certain places of worship, such as spirits of a tree or protector gods of a certain place, gods of a certain village, and so on.

4. Plants and animals are considered to have souls or spirits.

5. Supernatural entities in Japanese people beliefs concern the presence of great or high gods, lower or lesser gods (deities), souls, and spirits.

In addition to Japanese society concepts of the supernatural as explained above, Japanese society also possesses concepts of souls and spirits in the essence of ancestral spirits that the people believe, and the following is the explanations for these concepts:

1) The power of spirits: this concept regards the manifestation of goodness and manifestation of evil of spirits. People in Japanese society believe in spirits that are considered dangerous, therefore tending to manifest evilness or malevolence. There are also spirits yang that are not considered dangerous, having the tendency not to endanger human beings, and are thus considered good spirits.

2) Spirits of people that have died: these spirits are considered dangerous because they have just been separated from physical bodies and are considered contaminated, 
especially of people who died unnaturally. They are given offerings and prayers; if not, then the families they leave behind will experience misfortunes.

3) Purification of spirits of the dead in stages: the purification includes giving offerings and prayer. The offerings can be in the form of the favorite food of the person who died. If there is something that the person who died dislikes, such as children crying, then the children are kept away from the place of prayer.

4) Spirits that do not come from human beings: in addition to human beings, other creatures also possess spirits, such as animal spirits of animals. Although animal spirits are not worshipped at the family altar or in places of burial, these spirits may affect the fortune and misfortune of people.

In addition, according to Danandjaja (1997, p. 189), there are also concepts concerning possession and vengeance in Japanese people beliefs. Possession (tsukimono) is one way that the spirits can affect the lives of human beings. Living creatures possess the capability to possess other living creatures such as human beings, whether alive or dead, as well as animals. Exorcism is conducted on spirits that possess victims, such as by binding victims and beating them until the possessing spirits leave the victim, or summoning Shinto or Buddha priests to cast mantras, say prayers, perform ceremonies, and so on. This phenomenon of being possessed, according to Yoshida (Danandjaja, 1997) commonly occurs in rural regions in Japan.

Mystical vengeance (tatari) or punishment, according to Seki (in Danandjaja, 1997, p. 192) may occur in any of the following circumstances:

1) If a shrine or place is moved and the gods or spirits that reside there are not pleased with the place being moved.

2) If two or more incompatible gods are made to reside a single shrine together.

3) If a god is abandoned or not cared for appropriately.

4) If a person curses or intentionally leaves behind a god.

5) If a taboo is violated, such as by opening a forbidden door or any other action.

6) If a person dies unnaturally, whether killed or otherwise.

7) If a person kills or injures certain animals such as dogs, cats, snakes, and others. 


\section{RESEARCH METHOD}

The method of this research is descriptive qualitative. The data used in this research is dialog that is supported by clips or screenshots from the anime Natsume Yuujinchou that depict beliefs of Japanese people. The source for the data used in this research is the anime Natsume Yuujinchou of the first season (2008) with 13 episodes, second season (2009) with 13 episodes, third season (2011) with 13 episodes, and fourth season (2012) with 13 episodes.

The data collection technique used in this research is the technique of observing and recording. The observe-and-record technique, according to Kesuma (2007), is a technique of collecting data by recording data observation results on data cards. Data collected from written sources, for example, can be immediately recorded in data cards. The utilized data cards may be in the form of print paper, poster paper, card stock, or other paper appropriate to the language units to be recorded on the data cards. The following are the steps for data collection in this research:

a. Watching and observing carefully and thoroughly the anime Natsume Yuujinchou from the first through the fourth seasons, up to watching each season five times, in order to understand the storyline well as the primary data of the research.

b. Recording the important parts, which are dialogs that address Japanese people beliefs in the anime Natsume Yuujinchou from the first season to the fourth season, along with the accompanying intrinsic elements such as theme, characters, plot, and setting. These are accompanied by clips or screenshots for supporting data.

c. Classifying the data that have been collected according to the problem formulation.

The data analysis technique used in this research refers to Siswantoro (2013) who outlined that data analysis is conducted in explanations in descriptive form for all data in a functional and relational manner. The following are the steps for data analysis:

a. Describing the data collected from the data sources, as dialogs and clips or screenshots that depict Japanese people beliefs in the anime Natsume Yuujinchou from the first season to the fourth season, along with the accompanying intrinsic elements such as theme, characters, plot, and setting. 
b. Analyzing the data collected from the data sources according to theoretical review and data related to Japanese people beliefs.

c. Drawing conclusions from the collected data according to the research focus.

Validation, according to Sugiyono (2009, p. 267), is finding the precision between data occurring with the research object and the data reported by the researcher. In this research, the utilized technique is data triangulation. The data triangulation technique, according to Moleong (2010, p. 330), is the technique of data validation that utilizes other sources outside the data in order to check or compare the data. In this research, data was clarified by not only watching the anime repeatedly, but also recording the results of careful listening (choukai); to clarify the actual data in the form of dialogs in the anime, this was done by seeking the Japanese-language transcripts of the anime from trusted sources.

\section{Result and Discussion}

\subsection{Belief in the presence of the figures of gods}

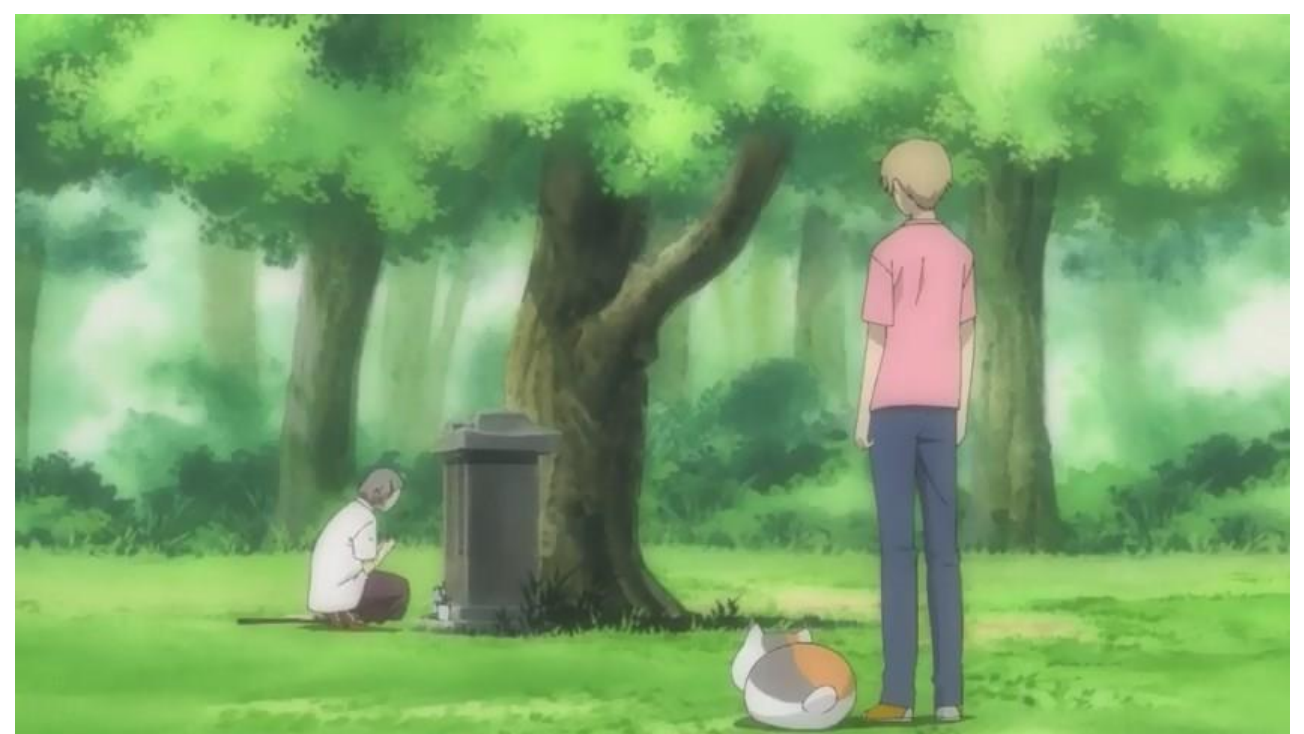

Figure 1. Natsume with Nyanko Sensei visiting the temple of the God of Dew

In dialog 14, Natsume Takashi and Nyanko Sensei visited the shrine of the resting place of Tsuyu Kami (God of Dew) because the God of Dew asked Natsume to visit his shrine. Natsume initially doubted the figure of the God of Dew since he was not quite a renowned figure like the God of Sun or God of Lightning, who are part of the high pantheon of gods, and 
the God of Dew is considered a minor god; after seeing the shrine of the God of Dew, Natsume believed and did not realize the figure of the god actually existed. Even so, the God of Dew himself admitted that he was previously not a god, but because there were people who prayed to him, he then possessed the figure of a god.

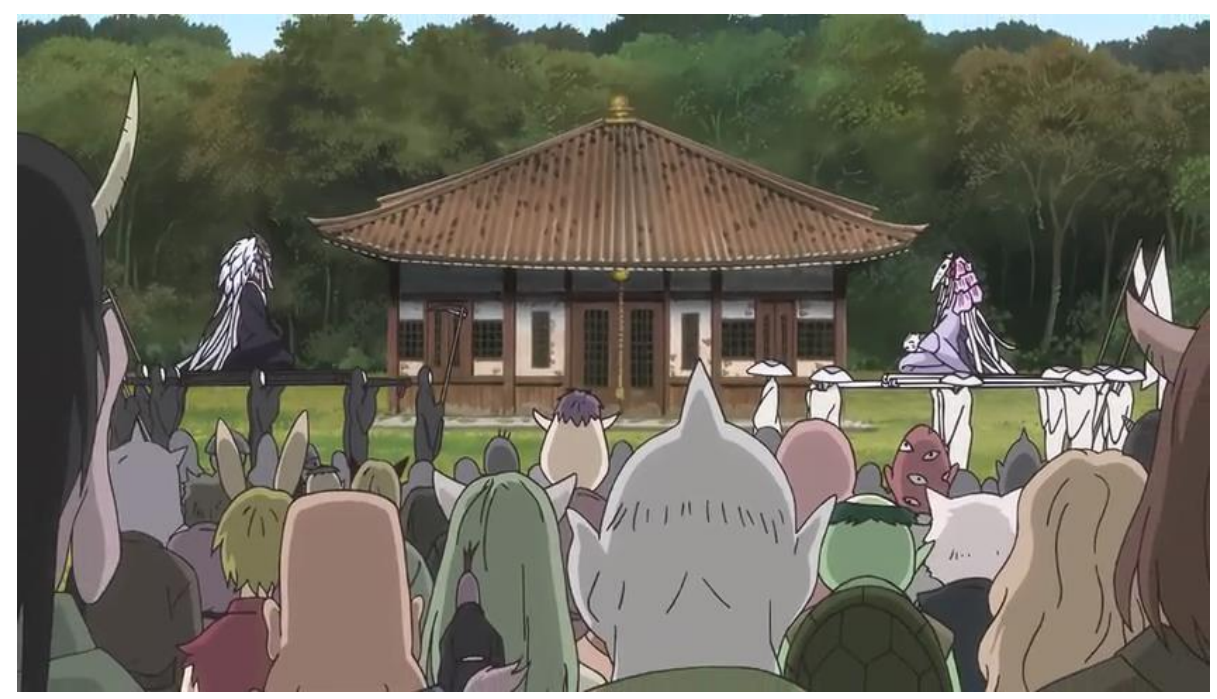

Figure 2. Houdzukugami meeting Fudzukigami before the match begins

In dialog 15, Natori Shuuichi, an eradicator of youkai, was asked by an uncle of an acquaintance of Natori, who suddenly contacted him. In a certain region, a harvest festival is held once every 10 years. The festival is believed by the residents of the region to bring together two gods of harvest, the god of abundant harvest (Houdzukugami) and the god of harvest failure (Fudzukigami). The residents of the region believe that their harvests are determined by the meeting of the two gods, but this belief is starting to disappear. Though the residents have started to forget the tradition of the harvest festival, the youkai are still expectant of the harvest festival and continue to hold the festival. Unfortunately, Houdzukugami was reported to have disappeared and was suspected to be inadvertently sealed by an eradicator of youkai. Natori Shuuichi was thus assigned to seek the god so that Fudzukigami did not win the festival that determined the result of harvests, thereby causing the harvests of this year to fail because Houdzukugami could not be present. 


\subsection{Belief of inanimate objects becoming animate if spirits enter them}

In dialog 16, when Natsume Takashi and Nyanko Sensei were on their way back, stopped by a park, and played with the snow, a youkai suddenly revealed itself from a statue. The youkai is called Gen, and Gen immediately attacked Natsume to try to possess him. However, Natsume dodged and Gen inadvertently entered a snow bunny sculpture made by Natsume. The snow bunny sculpture possessed by Gen now came to life.

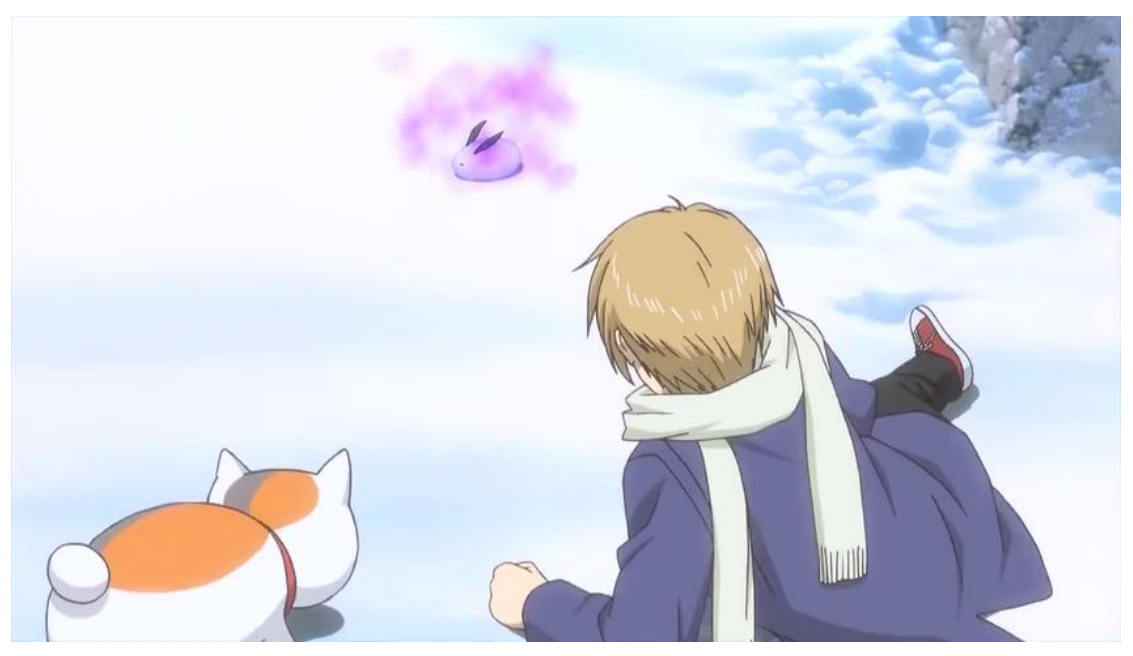

Figure 3. Gen possesses the snow sculpture created by Natsume

Dialog 16 is a reflection of the belief of Japanese people concerning the concept of the mysticism of animate or inanimate natural phenomena, for which even manmade things have the potential of coming to life if possessed by spirits. This is evidenced by the line "you can make snow into something I can possess - you, human, are great" which indicates the figure of Gen as a spirit that possesses an inanimate object, in this case being a snow bunny sculpture. The snow bunny sculpture, being a human creation, came to life after a spirit entered it. 


\subsection{Belief in mystical vengeance or punishment}

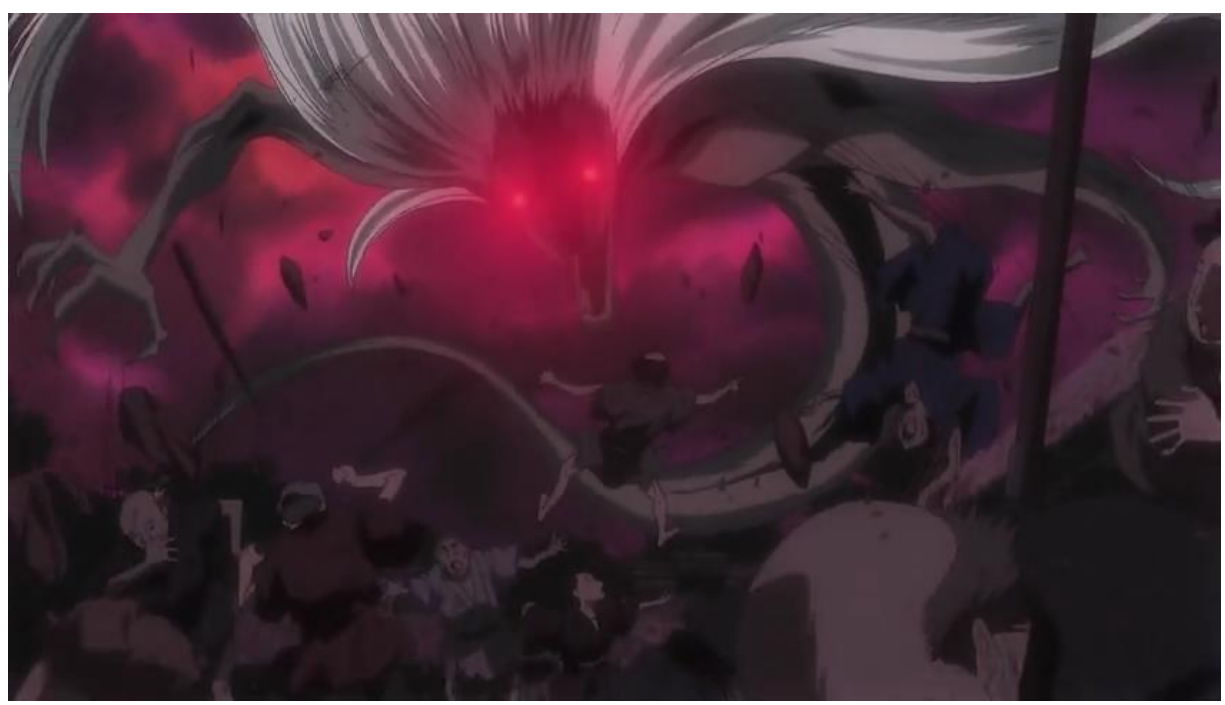

Figure 4. The wrath of Sui on village residents

In dialog 17, Gen told the story of the previous life with Sui, who is the partner of Gen, to Natsume Takashi and Nyanko Sensei. Gen and Sui are guardian spirits of a certain region, or could be considered as gods of purification. Both occupy the statue of Shiba no Hara, and the statue is worshipped for their guardian spirits by the surrounding residents. When they have successful harvests, the residents often give offerings in the form of their harvest to express their gratitude. However, one day their harvests failed, and the residents complained to the two spirits, blaming the harvest failure on them. The residents then destroyed their two statues. Then, one of the statues occupied by Sui was destroyed and discarded over a cliff, destroying its form. Sui then unleashed vengeance on the village residents by attacking them.

\subsection{Belief in the manifestation of goodness and evil of spirits}

In dialog 18, Natsume Takashi happened to find a teacup that turns out to be the figure of a youkai named kagechawan. Natsume then asked Nyanko Sensei about the teacup. Nyanko Sensei explained that the teacup was originally an ordinary teacup that had broken down and was discarded by its owner; after some time, spirits then entered the teacup and it became a youkai. Yet the teacup youkai is not dangerous or disruptive to people. Further, if a disaster is about to affect the house where the teacup resides, the teacup will run around the house to 
warn people living in the house. The teacup will then sacrifice its own life to prevent the impending disaster toward the house.

In dialog 19, Natori Shuuichi told Natsume Takashi about the task that he currently possesses to eradicate youkai in an old warehouse. The youkai had been disruptive to people, and thus Natori Shuuichi was tasked to eradicate them. If someone entered the old warehouse, such as a collector, the person would be afflicted by illness, disasters, or other misfortunes.

Dialogs 18 and 19 reflect one of the beliefs of Japanese people on the concept of souls and spirits, which is that the powers of spirits are the manifestation of evil and manifestation of goodness of those spirits. In dialog 18, the teacup, which has turned into a spirit, possesses the power of that spirit. The teacup represents a reflection of the manifestation of the goodness of a spirit; as it tends not to disrupt people and is not dangerous to them, it is considered a good spirit.

\subsection{Belief of souls or spirits in plants or animals}

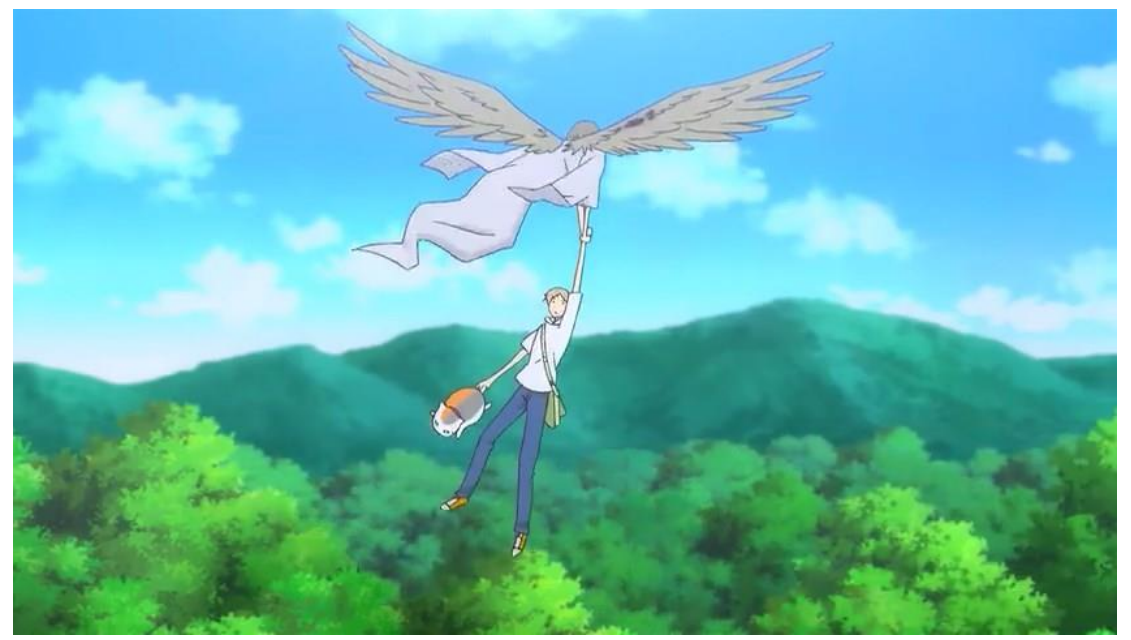

Figure 5. Youkai that takes the figure of a bird

In dialog 20, Natsume Takashi was approached by a female youkai to seek the aid of Natsume in finding a person that once helped her while she was still a little bird. The youkai wanted to meet with the person who once helped her and to interact with that person.

In dialog 21, Natsume Takashi and Nyanko Sensei was suddenly approached by Hotaru, a youkai whose true form is actually a firefly. However, Hotaru often takes the form of a woman. In the past, Hotaru was a friend with a person who often visited the lake where Hotaru lives. The person could see youkai in similar fashion to Natsume. However, the person now 
could no longer see and thus has never visited the lake. Hotaru asked Natsume to find the person and to become the mediator between Hotaru and the person.

Dialogs 20 and 21 reflect one of the beliefs of Japanese people on the supernatural concept of plants or animals being considered to have souls and spirits.

\section{Conclusion}

From the results of this data analysis we found five concepts of Japanese beliefs from anime, namely, 1) believing in the existence of gods; 2) believe in inanimate objects and can live if entered by the spirit; 3) conviction of revenge or invisible punishment; 4) belief in the manifestations of goodness and evil from the spirit; 5) belief in the soul (spirit) or spirit (spirit) in plants or animals. The conclusions of this study are Japanese beliefs contained in the anime Natsume Yuujinchou in the form of supernatural concepts, concepts of soul (soul) and spirit (spirit), and the concept of revenge (tatari).

\section{References}

Addis, S. (1985). Japanese Ghost and Demon. New York: George Braizler Inc.

Danandjaja, J. (1997). Folklor Jepang: Dilihat dari Kacamata Indonesia. Jakarta: PT. Pustaka Utama Grafiti.

Kesuma, T. M. J. (2007). Pengantar (Metode) Penelitian Bahasa. Yogyakarta: Caravastibooks. Koentjaraningat. (1998). Pengantar Antropologi II. Jakarta: PT. Rineka Cipta.

Lowie, R. H. (1937). The History Of Ethnological Theory. New York: Rinehart and Company. Moleong, L. J. (2010). Metodologi Penelitian Kualitatif. Bandung: PT. Remaja Rosdakarya Offset. Pertiwi, A. D. (2014). Analisis folklor Jepang dalam anime Gegege no Kitarouu, Inuyasha, dan Natsume Yuujinchou. Universitas Gadjah Mada.

Pranata dan Kebudayaan Jepang. (1976). Jakarta: Universitas Indonesia (UI-Press).

Ratna, N. K. (2011). Antropologi Sastra. Yogyakarta: Pustaka Pelajar.

Ross, C. (2007). Mistik Jepang: Supranatural and Mysterious Japan. Yogyakarta: Pinus Book. Siswantoro. (2013). Metode Penelitian Sastra. Yogyakarta: Pustaka Pelajar. Sugiyono. (2009). Metode Penelitian Kuantitatif, Kualitatif, dan R\&D. Bandung: Alfabeta. Warsito. (2012). Antropologi Budaya. Yogyakarta: Ombak. 